\title{
The resource allocation syndrome: the prime challenge of multi-project management?
}

\author{
Mats Engwall ${ }^{\mathrm{a}, *}$, Anna Jerbrant ${ }^{\mathrm{b}}$

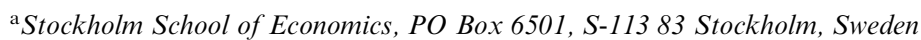 \\ ${ }^{\mathrm{b}}$ Royal Institute of Technology, S-100 44 Stockholm, Sweden
}

Received 22 January 2002; received in revised form 20 September 2002; accepted 11 December 2002

\begin{abstract}
This paper explores the nature of organizational settings, where a large extent of the operations is organized as simultaneous or successive projects. Anchored in qualitative case studies, the paper analyzes why the resource allocation syndrome is the number one issue for multi-project management and discusses the underlying mechanisms behind this phenomenon.
\end{abstract}

(C) 2003 Elsevier Ltd and IPMA. All rights reserved.

Keywords: Multi-project setting; Multi-project management; Project portfolio management; Resource allocation; Interdependencies

\section{Introduction}

Multi-project contexts and temporary systems are extensively common in contemporary business [1-3]. Even though influential thinkers [4,5] predicted this situation decades ago, research on these multi-project settings has traditionally been sparse. However, following the seminal work of Gareis [6], a number of articles have addressed issues such as multi-project scheduling [7], strategies for composing project portfolios [8-11], nature of program management [12-14], resource allocation between simultaneous projects [15-17], interproject learning [18], and organizing mechanisms in projectified organizations [19-22].

So far however, theories on multi-project settings have a limited empirical foundation; most of the contributions are either based on the author's practical experience or on research findings from one specific industry, one type of project, or one type of organization. We have little knowledge concerning which factors are context-specific and which factors are universal. Consequently, there is a need for comparative studies of multi-project settings from different contexts, with dif-

\footnotetext{
* Corresponding author. Tel.: +46-8-7369333; fax: +46-8-345811.

E-mail addresses: mats.engwall@hhs.se (M. Engwall), anna. jerbrant@lector.kth.se (A. Jerbrant).
}

ferent kind of project portfolios, and working under different environmental contingencies.

This paper gives a small contribution to such systematic, empirically based, cross-sectional analyses. Empirically anchored in comparative case study of multi-project management in two radically different organizations, it addresses the following two research questions;

(1) On a project portfolio-level, are there any operational problems that are gen-eral to multiproject management?

(2) If so, which underlying mechanisms of the multiproject setting cause these problems?

A multi-project organizational setting, as defined here, is constituted by an organizational unit that executes a substantial share of its operations as projects. Such a setting could be a result of an explicit strategy [23-25], but it could also be an unintended result, where many different projects with independent existence and separate goals, happen to run simultaneously [8]. In a multi-project setting there are several projects that are accomplished side by side, while drawing, at least some, resources from a common resource pool. This means that the projects are integrated into the management control and reporting system of some common resource pool owner [25], e.g. a general manager. 
In literature on multi-project management, the primary theme is the issue of allocation of resources between simultaneous projects $[17,25,26]$. Multi-project settings is describe as highly political, with a constant competition going on between different managers and projects concerning priorities, personnel, attention, and resources [13,27,28]. Most literature addresses multiproject resource allocation as a problem of a priori portfolio composition, planning, and scheduling $[10,13,17,25,29]$. There are only a few studies reported on the dynamics of multi-project settings and how management tries to coordinate the portfolio in action.

This is one such study. In the next section, the research methodology and the empirical cases are outlined. In the following section the two cases are compared and a common pattern of management problems is identified. Thereafter, the underlying mechanisms to this "resource allocation syndrome" are analyzed. The paper concludes by outlining implications for research and practice.

\section{Empirical research}

\subsection{Method}

The empirical basis is two, qualitative case studies. The first case study was executed from April 1998 to June 1999 at a contract division of a major supplier of signaling systems for railways. The purpose was to generate concepts, theoretical models, and empirical issues, which would guide further studies on multi-project settings as an empirical phenomenon. In order to acquire an in-depth understanding of the practices an ethnographic approach was chosen. During 14 months, one researcher spent approximately 3 days a week at the company. As in most ethnographic research, several sources of data were used, e.g. observations, interviews, and studies of written material, such as project documentation, technical documents, minutes, company instructions, and memos $[30,31]$.

The second study was initiated in order to test the validity of the findings from the first case. It was carried out during the fall 1999 at an R\&D division of a middlesized, private telecom operator. This multi-project organization was chosen in order to contrast the organization in the first case. Consequently, the study had a similar research design, but it was executed over a third of the time period.

At the first study, 22 persons were formally interviewed, many of them several times. In the second study, the number of respondents was 15 . All interviews were semi-structured. They lasted between $1 / 2$ and $2 \mathrm{~h}$ and were recorded and transcribed.

Finally, the generated written description was in each case reviewed and discussed with key-informants. The cases are summarized in Table 1.

\subsection{Empirical setting one: the contract division}

The Contract Division was one out of four divisions in a middle-sized engineering company. The company was more than 100 years old and had a strong industrial tradition. During the time of the study, the company had approximately 500 employees, who engineered, produced, and installed signaling and safety systems for railways. The clients were railway operators, subways, and commuter train systems from all over the world. The sales for 1998 were US\$ 94 million, which made it one of the leading companies on the international market.

The Contract Division had a matrix organizational design. It had approximately 200 employees and was responsible for all engineering activities involved in the execution of major contracts (projects) to different clients all around the world ( $80 \%$ of the company's turnover). Twenty project managers coordinated the project activities, which were carried out by personnel at three engineering departments (40-70 engineers respectively). Most employees were engaged in several projects simultaneously. Each department had the technical responsibility for a specified set of products. Due to safety requirements, all technical designs had to be approved by the department manager.

At the time of the study, the division had a portfolio of approximately 30 projects. The size of these projects varied between US\$ 0.3 and 17 million in budget, and 1 and 5 years in duration. Their scopes varied from improvements of existing designs and products, to deliveries of entirely new systems for new clients. The projects were based a few, common technical platforms; however each project was technically complex and comprised tailored applications for each specific client.

\subsection{Empirical setting two: the $R \& D$ Division}

The R\&D Division was one out of six divisions within a middle-sized, private telecom operator. At the time of the study the company was only four years old (founded in 1995), but it had the third biggest telecom capacity in the country. It owned and operated networks for telecommunication, data communication and Internet. In 1998, it had approximately 500 employees and its turnover was US\$ 150 millions.

The R\&D Division was formed during the spring of 1999 in order to facilitate a creative environment for the development of products and services. The division engaged approximately 50 employees, localized together at an office formed by a couple of old down town apartments.

The R\&D Division had a matrix structure. It had five specialist departments (2-15 employees/department) and one department for project management with seven project managers. All together, these project managers coordinated $12-15$ project assignments. However, the 
Table 1

The empirical cases in summary

\begin{tabular}{|c|c|c|}
\hline & Signaling systems, Contract Division & Telecom operator R\&D Division \\
\hline \multicolumn{3}{|l|}{ Organisation } \\
\hline Scope & $\begin{array}{l}\text { Execution of complex contracts on } \\
\text { turn key basis for international clients }\end{array}$ & $\begin{array}{l}\text { Business and product development of new telecom services, } \\
\text { implementation of telecom infrastructure technical support } \\
\text { of existing products }\end{array}$ \\
\hline Size & Approx. 200 employees & Approx. 50 employees \\
\hline Department structure & $\begin{array}{l}\text { Five departments: } 3 \text { engineering, } 1 \\
\text { administration, } 1 \text { project management }\end{array}$ & $\begin{array}{l}\text { Six departments: product management, technical development, } \\
\text { business development, IT-systems, juridical issues, project } \\
\text { management }\end{array}$ \\
\hline Project management structure & $\begin{array}{l}\text { Matrix structure: all projects cross-functionally } \\
\text { coordinated by project managers at the project } \\
\text { management department. }\end{array}$ & $\begin{array}{l}\text { Matrix structure: projects cross-functionally coordinated by } \\
\text { project managers at different positions in the organization. }\end{array}$ \\
\hline \multicolumn{3}{|l|}{ Projects } \\
\hline Number of projects & Approx. 30 & Approx. 60 (20 had official priority) \\
\hline Size & Budget: US\$ $0.3-17$ million Duration: $1-5$ years & Budget: US\$ 0-6 million Duration: $\frac{1}{2}-2$ years \\
\hline Technical complexity & High & Low \\
\hline Uncertainty in the projects & Primarily technical uncertainties & Primarily market uncertainties \\
\hline Prime emphasis & Product performance, effectiveness & Time, creativity \\
\hline \multicolumn{3}{|l|}{ Project portfolio } \\
\hline Structure & $\begin{array}{l}\text { Execution of tailored system applications from a } \\
\text { specified set of generic technological platforms }\end{array}$ & $\begin{array}{l}\text { Execution of a vast array of different types of projects with } \\
\text { different background }\end{array}$ \\
\hline Resource interdependencies & High, due to use of common resources & High, due to use of common resources \\
\hline Technical interdependencies & High, due to use of common platforms & Low \\
\hline \multicolumn{3}{|l|}{ Project management system } \\
\hline Project management model & $\begin{array}{l}\text { Company specific, compiled in a project } \\
\text { handbook }\end{array}$ & Division specific, superficial draft on 10 pages \\
\hline Project management procedures & Standardized & Non-standardized \\
\hline Steering committees & Project portfolio, company level & Project portfolio, division level \\
\hline
\end{tabular}

technical work was always carried out at the specialist departments. Most employees were engaged in several projects simultaneously.

At the time of the study, there were approximately 60 projects defined in the division's portfolio. The projects ranged in type from capital investments of several million dollars to feasibility studies or minor improvement of Internet home pages. Project budgets ranged from US\$ 0 to 6 million, and schedules from $\frac{1}{2}$ to 2 years. Technically, the projects were relatively simple; however the fast-moving telecom market generated significant uncertainties concerning their scopes.

\section{Results}

At the Contract Division as well as the R\&D Division, the operations were constituted by an array of projects sharing resources with limited interchangeability due to technical specialization. Both organizations were matrix structured; projects were crossfunctionally coordinated and executed by personnel from different specialist departments. However, a comparison between the two multi-project settings demonstrates significant differences.

\subsection{Differences}

First, the scope of the operations was different. While the Contract Division delivered and installed major systems on contracts from external clients, the R\&D Division primarily developed new products and services to be implemented in the company's own, internal telecom network. Thus, while the rationality of the Contract Division was to include as little technical innovation as possible in the projects in order to be cost efficient, the rationality of the R\&D Division was to be as innovative as possible in order to attract new subscribers to the company. In addition, the Contract Division executed projects world wide, while the R\&D Division was concentrated on the domestic telecom market.

Second, the complexity of the projects differed. The Contract Division ran many large, technically advanced projects, with long duration, comprising a large number of different technical sub-systems and components, and with a strong emphasis on performance and technical security of the final products. The projects of the R\&D division were on average much smaller, had shorter duration time, and were not as technically complex. Furthermore, when the uncertainty of projects in the 
Contract Division was due to the process of how to engineer the contracted functions, the uncertainty of the projects in the R\&D Division was primarily due to the problem of what to produce.

A third difference was historical. While the Contract Division had a long industrial tradition of being one of the leading actors on their international market, the R\&D Division was newly created and belonged to a company which was less than 5 years old and impregnated by the telecom and Internet hype of the late 1990s. This difference pinpoints the fact that while the Contract Division had a mature and comprehensive system for project management, the procedures of the R\&D Division was immature, crude, and unsophisticated.

Finally, the compositions of the project portfolios differed. The Contract Division had a divergent project portfolio; the different projects were constituted by client contracts comprising tailored systems, however based on a small number of generic technical platforms. The R\&D Division handled a more scattered portfolio, comprising projects of many different types and origins but with a common outlet: the company's telecom network. Consequently, the projects of the divisions were different, both in content and form.

\subsection{Common characteristics}

In spite of these differences, the dynamics of the project portfolios and the way the two organizations tried to manage their portfolios were quite similar. On this aggregate level, the two cases illustrate an almost identical pattern of problems and difficulties, as well as problem solving strategies. In many ways the management teams of the two divisions were facing the same challenges of multi-project management (for typical interview extracts, see Table 2).

First, both project portfolios were characterized by extensive project interdependencies. At the Contract Division, several of the projects were suffering from problems concerning significant delays, and strained customer relations, for one thing because of a major change in platform technology. Most projects were dependent on the same resources (personnel) for their execution, which meant that scheduling of the resource allocation was significantly important. When one project had problems, other projects were affected directly, either because personnel were redistributed, or because necessary technical solutions were not available as scheduled.

At the R\&D Division, there was a wide spectrum of different types of projects, with different size, scope, technology, and backgrounds. Even though the division did not have any external customers of its own, project lead-time was a primary concern. There was a strong emphasis on launching new, creative services on the fast moving telecom market before any of the competitors did. The projects were not technically closely coupled, but they were dependent on contributions from the same limited number of persons. Thus, as in the Contract Division, delays and disturbances within one project often had negative effects on several other projects as well.

Secondly, in both organizations the primary everyday portfolio management issue was priority setting and resource re-allocation. Both divisions had a steering committee, for periodical review and control of the project portfolio, and a "project boss", for dealing with operational matters beyond the project managers' authorities. At both divisions however, portfolio management was overwhelmed with issues concerning prioritization of projects and the distribution personnel from low-prioritized, or smoothly going, projects to high-priority projects or projects in urgent crises. Most of the time however there were no slack resources available and when resources were redistributed it often produced negative effects on unanticipated places in the project portfolio.

Thirdly, in both organizations there was a tough competition between projects. There was a continuously ongoing game of negations concerning access to available resources and the allocation of certain individuals to specific projects. Due to ambiguous cause-effects relationships, unclear project priorities, and conflicting interests between different projects and departments, unsettled issues were frequently boosted up through the organizational hierarchy to be resolved by portfolio management. Consequently, portfolio management level was overloaded with problems.

Finally, management in both organizations was primarily engaged in short term problem solving. Due to the troubles in many projects, both the steering committees and middle management were occupied with ad hoc problem solving. Long-term knowledge development or process improvements, which might have been fruitful to the portfolio as a whole, were always subordinated to short-term problem solving in different singular projects. Consequently, there was a widely spread feeling of inefficiency in both organizations.

\section{The resource allocation syndrome of multi-project management}

The first research question of this study addressed whether there are any operational portfolio management problems that are common for multi-project settings? The current findings indicate that there is.

The common pattern of the two cases constitutes a "resource allocation syndrome". In both organizations, the primary management issue revolved around resources. The portfolio management was overwhelmed with 
Table 2

Typical interview statements

\begin{tabular}{|c|c|c|}
\hline & Signaling systems, Contract Division & Telecom operator, R\&D Division \\
\hline $\begin{array}{l}\text { Project interdependencies } \\
\text { and lack of resources }\end{array}$ & $\begin{array}{l}\text { "We have } 20-30 \text { ongoing projects at the same time, } \\
\text { then one project is delayed, and all our planning is } \\
\text { disturbed. And this doesn't affect only this single } \\
\text { project, instead everything slips away and ends up } \\
\text { on top of each other." Department manager }\end{array}$ & $\begin{array}{l}\text { "We have the desire to do something but often } \\
\text { there is a lack of time and resources if we should } \\
\text { go for something. So when we go to the other } \\
\text { departments they tell us they don't have the } \\
\text { resources to do this." Project manager }\end{array}$ \\
\hline $\begin{array}{l}\text { Priority setting and resources } \\
\text { reallocations }\end{array}$ & $\begin{array}{l}\text { "It never goes exactly as planned. Something's will } \\
\text { take longer, and other things come in between. } \\
\text { People here doesn't work only with my project, } \\
\text { they have other things to do also. So then something } \\
\text { takes longer to do they're supposed to, don't go as } \\
\text { fast as planned. Then you don't reach the project } \\
\text { goal because of the resource situation we've got." } \\
\text { Project manager }\end{array}$ & $\begin{array}{l}\text { "We do have the will to execute all of these } \\
\text { new ideas. But what is lacking is the resources } \\
\text { and an outspoken strategy of what we should } \\
\text { focus on." Project manager } \\
\text { "We have a } 80-20 \text { relationship today. We can } \\
\text { only do } 20 \% \text { of all the things we want to do. } \\
80 \% \text { aren't we able to handle, so you really } \\
\text { have to prioritize." Department manager }\end{array}$ \\
\hline Competition between projects & $\begin{array}{l}\text { "Today, the most common reason for conflicts is } \\
\text { the instant lack of competent personnel. Why did } \\
\text { that project get so much better project members } \\
\text { than mine? Furthermore, the project managers } \\
\text { sometimes want to know why their project isn't } \\
\text { prioritized when another project is." } \\
\text { Department manager }\end{array}$ & $\begin{array}{l}\text { "Many times when we go out in the organization } \\
\text { and try to find resources for our projects we get } \\
\text { the answer that there aren't any available. So } \\
\text { then there are a lot of arguments..." Project } \\
\text { manager }\end{array}$ \\
\hline Short term problem solving & $\begin{array}{l}\text { "[That in every problematic situation] run around } \\
\text { and straiten things out, and have to talk to ten } \\
\text { different people, and get ten different answers is } \\
\text { very frustrating. ... Maybe, we should arrange } \\
\text { a training camp in internal procedures." } \\
\text { Project manager }\end{array}$ & \\
\hline
\end{tabular}

issues concerning prioritization of projects and, distribution of personnel from one project to another, and the search for slack resources. However, there were no resources available. Furthermore, when resources were redistributed it often produced negative effects on other projects of the portfolio. This forced the management to continuous fire fighting, resulting in reactive behavior and short-term problem solving. However, the primary lever for portfolio management to affect an ongoing project in trouble was resource re-allocation.

This is the answer to the first research question; the identified syndrome seems to be connected to the multiproject setting per se, independently of project type, size, industrial context, and individual project participants. Thus, the findings verify the picture in literature of the difficulty of planning, scheduling, and allocating resources between different, simultaneously ongoing projects. Furthermore, the strong notion of scarcity of resources in the empirical cases aligns well with findings from most other studies of multi-project settings $[13,15,17,25,29]$.

\subsection{Mechanisms influencing resource demand}

In the following paragraphs we address some of the possible causes to this syndrome. Even though our empirical basis is limited, the Contract Division and the R\&D Division provide us with some indices concerning what organizational mechanisms that cause the syndrome. In other words, what are the underlying mechanisms behind the resource allocation problem?

One answer is that the syndrome is an effect of failing project scheduling. This is the most discussed reason in the literature $[7,16]$. By appropriate multi-project scheduling, employed resources are supposed to move from one project to another as in an efficient machinery. Hence, in both the empirical cases, the organizations tried to run a centralized resource planning system where personnel were allocated to different projects with respect to time schedules and official project priorities. However, since many projects lagged behind their schedules, the resource utilization that was scheduled to a certain point in time was often not possible to activate. Instead of a priori planning, the resource allocation process was transformed into an issue of "after-the-factprioritization" between ongoing projects.

Another answer is that the syndrome is an effect of over commitment, i.e. too many projects in relation to existing level of resources. In literature, this is claimed to be the typical situation in multi-project settings [25]. As Spühler and Biagini [31] state it "there is hardly a company to be found which does not launch more projects 
than it can master with available resources". Clark and Wheelwright [26] call it the "canary cage approach" to portfolio planning, i.e. that new canaries (projects) are thrown into the cage without any analysis of the effects of the other canaries already in the cage. Both empirical cases correspond with this picture. However going through a major shift in platform technology, the parent company of the Contract Division did not stop adding new projects to the portfolio. Winning new contracts was always the primary concern. At the R\&D division, on the other hand, a large number of business opportunities had been identified and as a response several initiatives were taken, but nobody knew how to prioritize between them.

\subsection{Mechanisms influencing resource supply}

By addressing the demand side, the two explanations above follow the traditional line of reasoning in the literature. In both explanations, the existing level of resources is treated as an independent variable, and the problem is the resource demand at a specific situation. However, by analyzing the resource supply side, we inquire into factors usually not discussed in theories on multi-project management. The current findings provide us with some ideas about how structures and behaviors influence the supply side of the syndrome. Based on the cases, we will highlight two aspects:

First, the resource allocation syndrome might be an effect of management accounting systems that are dysfunctional for multi-project management. One example is the Contract Division where each department got reimbursed for engineering hours spent on contracted projects based on a cost-plus principle. This was the "income" to the departments, while non-project time, such as department meetings, education, and idling, was accounted as costs. Thus, the financial incentive for departments were to spent as many engineering hours as possible on each singular project. Thus, there were little financial incentives for productivity improvements.

At the R\&D Division, engineering hours was not accounted at all. Thus, neither portfolio management, nor the project or department managers, had any aggregate information about what the personnel actually were doing during in their projects. Consequently, they had very limited data concerning potential efficiency improvements at the division.

Secondly, the syndrome might be an effect of opportunistic project management behavior within the organizations. This type of process was a significant constituent of the political games of the two cases. In these matrix organizations, one way for a project manager to acquire the best experts was to furnish the project with high priority from top management. If this was impossible by ordinary means, i.e. by arguing for higher priority than the other projects of the portfolio, an alternative for the project manager was to push the project to such a crisis that the project has to gain priority if it should survive at all. In addition, if a project manager actually left resources to other projects, there was a major risk that these resources would not come back again when he or she needed them. Thus, from a project manager's point of view, acquired resources should be protected from other projects as long as possible, for instance by keeping them occupied, busy, and unavailable.

\section{Conclusions}

This study explores management challenges that are general to multi-project management and discusses some plausible underlying mechanisms that cause these challenges. Obviously, the article has a limited empirical basis. However, since the two cases are taken from significantly different contexts, but still illustrated significant commonalities, we believe that the findings indicate something important.

The identified resource allocation syndrome validates the established theoretical picture. However, while past research has treated this syndrome primarily as a planning and scheduling issue, current findings illustrate that this explanation is too simplistic. As shown, the allocation of resources to (and between) simultaneous and successive projects is a process of politics, horse trading, interpretation, and sense making that is far more complex than traditionally has been discussed.

The implication is that research on multi-project management has to go beyond resource allocation and start addressing incentive structures, accounting systems, and other deeply embedded features of the organization. As shown, managing a business structured as multiple projects does not mean to superimpose an extra level of coordination on traditional business systems and structures. Instead of more scheduling, progress reports, or more time spent on review meetings, the whole system of managerial procedures has to be reconceptualized from its roots. As current findings indicate: the resource allocation syndrome of multi-project management is not an issue in itself; it is rather an expression of many other, more profound, organizational problems of the multi-project setting.

\section{References}

[1] Rugirok WPA, Peck S, Fenton E, Conyon M. Corporate restructuring and new forms of organizing: evidence from Europe. Management International Review 1999;39(2):41-64.

[2] Turner R. Handbook of project based management. second ed. London: McGraw-Hill; 1999.

[3] Whittington R, Pettigrew A, Peck S, Fenton E, Conyon M. Change and complementarities in the new competitive landscape: 
a European panel study, 1992-1996. Organization Science 1999; 10(5):583-600.

[4] Bennis WG, Slater PE. The temporary society. New York: Harper \& Row Publishers; 1968.

[5] Toffler A. Future shock. London: Pan Books; 1970.

[6] Gareis R. Management by projects-organization, structure and control. International Journal of Project Management 1989;7(4).

[7] Wiley VD, Deckro RF, Jackson JA. Optimization analysis for design and planning of mulit-project portfolios. European Journal of Operational Research 1998;107:492-506.

[8] Anell B. Managing project portfolios, in Projects as business constituents and guiding motives. In: Lundin RA, Hartman F. Boston: Kluwer Academic Publishers; 2000.

[9] Cooper RG, Edgett SJ, Kleinschmidt EJ. Portfolio management for new products. New York: Persues Books; 1998.

[10] De Maio A, Verganti R, Corso M. A multi-project management framework for product development. European Journal of Operational Research 1994;78:178-91.

[11] Englund R, Graham RJ. Linking projects to strategy. Journal of Product Innovation Management 1999;16(52):52-64.

[12] Turner RJ, Speiser A. Programme management and its information systems requirements. International Journal of Project Management 1992;10(4):196-206.

[13] Platje A, Seidel H, Wadman S. Project and portfolio planning cycle: project based management for the multiproject challange. International Journal of Project Management 1994;12(2):100-6.

[14] Pellegrinelli S. Programme management: organising projectbased change. International Journal of Project Management 1997;15(3):141-9.

[15] Eskeröd, P., Nye perspektiver på fordeling af menneskilge ressourcer $\mathrm{i}$ et projektorganiseret multiprojekt-miljö, in Ehrversökonomi.Handelshöjskole Syd i Sönderborg. 1997.

[16] Gordon J, Tulip A. Resource scheduling. International Journal of Project Management 1997;15(6):359-70.

[17] Hendriks M, Voeten B, Kroep L. Human resource allocation and project portfolio planning in practice. International Journal of Project Management 1999;17(3):181-8.

[18] Nobeoka K. Inter-project learning in new product development. Academy of Management Journal 1995;38(4):432-6.
[19] Brown SL, Eisenhardt KM. The art of continuous change: linking complexity theory and time-paced evolution in relentlessly shifting organizations. Administrative Science Quarterly 1997; 42(1):1-34.

[20] Hobday M. The project based organisation: an ideal form for managing complex products and systems? Research Policy 2000; 29:871-93.

[21] Lindkvist L. Det projektbaserade företaget. In: Berggren C, Lindkvist L, editors. Projekt: Organisation för målorientering och lärande. Lund: Studentlitteratur; 2001.

[22] Selin, G., Selin, M. Reason for project management failure in multiproject environment using matrix organization. In Proceedings of 11th International Project Management Congress INTERNET. 1992. Florence.

[23] Turner R, Keegan A. Mechanisms of governance in the projectbased organization: the roles of the broker and steward. European Management Journal 2001;19(3):254-67.

[24] Ferns DC. Developments in programme management. International Journal of Project Managment 1991;9(3):148-56.

[25] Payne JH. Management of multiple simultaneous projects: a state of the art review. International Journal of Project Management 1995;13(3):163-8.

[26] Clark KB, Wheelwright S. Revolutionizing product development: quantum leaps in speed, efficiency, and quality. New York: The Free Press; 1992.

[27] Eskeröd P. Meaning and action in a multi-project environment. International Journal of Project Management 1996;14(2):61-5.

[28] Eskeröd P. The human resource allocation process when organizing by projects. In: Lundin R, Midler C, editors. Projects as arenas for renewal and learning processes. Boston, Massachusetts: Kluwer Academic Publishers; 1998. p. 125-31.

[29] Wheelwright SC, Clark KB. Creating project plans to focus product development. Harvard Business Review, March-April 1992:70-82.

[30] van der Merwe AP. Multi-project management - organizational structure and control. International Journal of Project Management 1997;15(4):223-33.

[31] Spühler RW, Biagini RG. The role and weaknesses of top management in internal projects. In: Gareis R, editor. Handbook of management by projects. Vienna: Manzsche Verlag; 1990. 